\title{
MARINE ECOSYSTEM SERVICES IN XÀBIA, NORTH OF ALICANTE (SPAIN): AN ECONOMIC VALUATION VIA MULTICRITERIA ANALYSIS
}

\author{
Ana María Gómez-Aguayo ab*, Vicent Estruch-Guitart ${ }^{\mathrm{b}}$
}

\author{
a INGENIO (CSIC-Universitat Politècnica de València), Camino de Vera s/n, E-46022 Valencia, Spain; \\ angoag@upvnet.upv.es \\ ${ }^{b}$ Department of Economics and Social Sciences, Universitat Politècnica de València, Valencia, Spain; \\ vestruch@esp.upv.es
}

\begin{abstract}
This paper provides an estimation of the economic value of the Ecosystem Services (ESs) in the marine coastal strip of Xàbia, north of Alicante, Spain. The proposed method combines an Analytic Network Process (ANP) and a Discounted Cash Flow model. We confirmed the presence of seven ESs in this natural area (including seafood, climate regulation, waste treatment, biological control, lifecycle maintenance, gene pool protection, recreation, cultural heritage, and knowledge development) based on the Economics of Ecosystems and Biodiversity classification. Our results reveal substantial economic value attached to nonmarketed services provided by the underwater environment.
\end{abstract}

Keywords: economic valuation; multicriteria analysis; ecosystem services; marine ecosystems.

\section{Introduction}

Coastal and marine ecosystems fulfil a variety of ecological functions or Ecosystem Services (ESs) that contribute directly and indirectly to human well-being (Barbier, 2007; Costanza, 1999; Jobstvogt et al., 2014; Millennium Ecosystem Assessment, 2005). In the context of a marine environment, they translate into food production, coastline stabilization, Carbon Dioxide (CO2) sequestration, ecosystem stability, shelter and other direct recreational and cultural benefits for human beings (Deegan, 1993; Remoundou et al., 2009).

Several different authors and organizations have proposed ecosystem services classifications e.g., Costanza et al. (Costanza et al., 1997); MEA (Millennium Ecosystem Assessment, 2005); TEEB (2010); HainesYoung \& Potschin (2012) and some authors have adapted these to the marine environment (e.g., Atkins et al. (2011); Böhnke-Henrichs et al. (2013); Hattam et al. (2015); Liquete et al. (2013). In this study, we use the ES typology adapted to marine ecosystems proposed by Böhnke-Henrichs et al. (2013) who build on The Economics of Ecosystems and Biodiversity (TEEB) (2010) framework. This is a comprehensive and consistent approach suited to future application to the European Union (EU) Marine Strategy Framework (Böhnke-Henrichs et al., 2013).

Assessments of marine ESs in Spain are scarce despite an increase in research on ES following publication of the Millennium Ecosystem Assessment (MEA) (2005) and TEEB (2010). The lack of information on this environment is not conducive to decisions about environmental policies, which are needed urgently to slow the depletion of the caused by increased human pressure and climate change (Black Sea Commission, 2009; Micheli et al., 2013; Rodríguez and Ruíz, 2010).

\section{Materials and Methods}

The proposed model includes: (i) definition of the study area; (ii) the ANP; (iii) estimation of the pivot value; and (iv) calculation of the monetary value of the ESs.

\subsection{Determining the area}

Xàbia is a municipality in the Valencian Community (Spain), located on the north coast of the province of Alicante. It extends from Cabo de San Antonio to the tip of Moraira and the infralittoral zone reaches a depth of 40 metres. The study area includes protected spaces such as the Marine Reserve of Cap de Sant Antoni, the Montgó Natural Park, Portitxol Bay the Granadella Forest, and the Penya-segats de la Marina Site of Community Importance (SCI). 


\subsection{Analytic Network Process}

ANP is a multicriteria decision technique developed by Thomas Saaty (1987) as an improved generalization of the Analytic Hierarchy Process (AHP) (Saaty 1990).

The ANP methodology uses only expert opinion; our selection of experts was based on two criteria. First, specialism in marine biology and second, work experience in the Xàbia natural marine area. The participating experts were affiliated to various institutions including the University of Valencia (UPV), the Catholic University of Valencia (UCV), the Oceanogràfic Foundation and other local institutes.

The second round of interviews with our four experts was conducted to analyse the influences among subcriteria and to complete the dependence matrix proposed by Saaty (2004).

The third round of interviews included face-to-face interviews with 14 experts to obtain their relative preference rankings for the criteria and sub-criteria. The design included: paired comparison among the three groups of ESs, that is, provisioning, regulatory and culture (model 1); paired comparison including habitat services (model 2); and corresponding sub-criteria comparisons according to the dependency matrix. The pair-wise comparisons were applied to both the criteria and sub-criteria using the fundamental scale matrix (Saaty 1988). This numerical scale takes values between 1 and 9, where (1) is equal importance and (9) is extremely important. The final results of both models were analysed statistically and classified by cluster to achieve a homogeneous response and coherency among the individuals surveyed (Innes and Pascoe, 2010; Mardle et al., 2004; Zahir, 1999). Finally, we aggregated the individual weights by cluster, which implied geometric mean transformation (Forman and Peniwati, 1998).

\subsection{Estimating the pivot value and the monetary value of ESs}

The DCF method involves a two-step process. First, the pivot value is determined by the market value of the provisioning services (seafood). The provisioning value is measured by the operating cash flow from artisanal fishing only. Second, the pivot value is updated at a social rate of discount. Ultimately, the value of the net cash flow of provisioning services is updated applying a SRTP equal to $3.25 \%$.

We obtained the total value of the services assessed in model 1 by summing the partial values for the provisioning, regulatory and cultural services. The individual value of each ES is calculated by distributing the total value obtained from model 1, according to the weights obtained in model 2.

\section{Results}

Seven ESs were identified: seafood, climate regulation, waste treatment, biological control, habitat, recreation and knowledge development.

The results of each model were analysed separately. The first model provides the weights of the ESs for the three groups of services (provision, regulatory and culture); the second model includes habitat services. Following statistical analysis of the output we determined the existence of two groups of experts with very different ES judgements. Table 1 present weights of ESs by the two ANP models.

Table 1. Final ESs weights by the two ANP models

\begin{tabular}{|c|c|c|c|c|}
\hline & \multicolumn{2}{|r|}{ ANP 1} & \multicolumn{2}{|r|}{ ANP 2} \\
\hline & $\begin{array}{c}\mathrm{C} 1 . \\
\text { Biologist }\end{array}$ & $\begin{array}{c}\mathrm{C} 2 . \\
\text { Environmentalist }\end{array}$ & $\begin{array}{c}\text { C1. } \\
\text { Biologist }\end{array}$ & $\begin{array}{c}\mathrm{C} 2 . \\
\text { Environmentalist }\end{array}$ \\
\hline ES1 & 0.09 & 0.15 & 0.07 & 0.12 \\
\hline ES2 & & & 0.32 & 0.31 \\
\hline ES3 & 0.10 & 0.08 & 0.06 & 0.05 \\
\hline ES4 & 0.27 & 0.28 & 0.18 & 0.16 \\
\hline ES5 & 0.36 & 0.39 & 0.24 & 0.30 \\
\hline ES6 & 0.10 & 0.05 & 0.04 & 0.02 \\
\hline ES7 & 0.09 & 0.05 & 0.08 & 0.05 \\
\hline
\end{tabular}

Note: ES1: Seafood; ES2: Habitat services; ES3: Climate regulation; ES4: Waste treatment; ES5: Biological control; ES6: recreation; ES7: Knowledge development.

We estimated the economic value of seafood based on the average of the last four cash flows available. Cash inflow considers the catches from artisanal fishing in the 2015 to 2018 campaigns (Valenciana, G, 2019). Cash outflows consider payments to suppliers and employees, other operating expenses, depreciation and income taxes. We used the value of seafood to calculate the total value of services from model 1 . Then to obtain a final ESs value, we used the total value obtained in model 1 as the weights of the four groups of services in model 2. 
Expressed by range of values (maximum or minimum) according to the group of experts, we obtained the following intervals of values: (ES1) seafood provision $€ 410-€ 439 / \mathrm{ha} / \mathrm{yr},(\mathrm{ES} 2)$ habitat services $€ 1,090$ $€ 1889 / \mathrm{ha} / \mathrm{yr},(\mathrm{ES} 3)$ climate regulation $€ 178-€ 329 / \mathrm{ha} / \mathrm{yr},(\mathrm{ES} 4)$ waste treatment $€ 555-€ 1,091 / \mathrm{ha} / \mathrm{yr}$, (ES5) biological control $€ 1,057-€ 1,449 / \mathrm{ha} / \mathrm{yr}$, (ES6) recreation $€ 80-€ 266 / \mathrm{ha} / \mathrm{yr}$ and (ES7) knowledge development $€ 175-€ 506 / \mathrm{ha} / \mathrm{yr}$.

\section{Conclusions}

The socio-economic well-being of coastal communities depends on the quantity and quality of the resources provided by the marine ecosystem. Robust information about the value of marine ES can inform policy makers to prioritize policies supporting the provision of environmental services and reducing the deterioration of the marine environment. This study identified and economically valued seven of the most predominant ESs in the marine area of Xàbia, Spain. Their evaluation allows a better estimation of the contribution of marine ecosystems to human well-being. The findings from this study should enhance communication and education related to the environment and inform actions that will have a positive impact on coastal localities.

\section{References}

Atkins, J.P., Gregory, A.J., Burdon, D., Elliott, M. (2011). Managing the Marine Environment: Is the DPSIR Framework Holistic Enough? Systems Research and Behavioral Science 28, 497-508.

Barbier, E.B. (2007). Valuing ecosystem services as productive inputs. Economic Policy 22, 178-229.

Black Sea Commission (2009). Implementation of the Strategic Action Plan for the Rehabilitation and Protectionof the Black Sea (2002-2007).

Böhnke-Henrichs, A., Baulcomb, C., Koss, R., Hussain, S.S., de Groot, R.S. (2013). Typology and indicators of ecosystem services for marine spatial planning and management. Journal of Environmental Management 130, 135-145.

Costanza, R. (1999). The ecological, economic, and social importance of the oceans. Ecological economics 31, 199-213.

Costanza, R., Hannon, B., Limburg, K., Naeem, S., O’Neill, R.V., Raskin, R.G., Sutton, P., (1997). The Value of the World's Ecosystem Services and Natural Capital 26.

De Groot, R.S., Fisher, B., Christie, M., Aronson, J., Braat, L., Haines-Young, R., Gowdy, J., Maltby, E., Neuville, A., Polasky, S. (2010). Integrating the ecological and economic dimensions in biodiversity and ecosystem service valuation, in: The Economics of Ecosystems and Biodiversity (TEEB): Ecological and Economic Foundations. Earthscan, Routledge, pp. 9-40.

Deegan, L.A. (1993). Nutrient and energy transport between estuaries and coastal marine ecosystems by fish migration. Canadian Journal of Fisheries and Aquatic Sciences 50, 74-79.

Forman, E., Peniwati, K. (1998). Aggregating individual judgments and priorities with the analytic hierarchy process. European journal of operational research 108, 165-169.

Hattam, C., Atkins, J.P., Beaumont, N., Börger, T., Böhnke-Henrichs, A., Burdon, D., Groot, R. de, Hoefnagel, E., Nunes, P.A.L.D., Piwowarczyk, J., Sastre, S., Austen, M.C. (2015). Marine ecosystem services: Linking indicators to their classification. Ecological Indicators 49, 61-75.

Innes, J.P., Pascoe, S. (2010). A multi-criteria assessment of fishing gear impacts in demersal fisheries. Journal of environmental management 91, 932-939.

Jobstvogt, N., Hanley, N., Hynes, S., Kenter, J., Witte, U., 2014. Twenty thousand sterling under the sea: Estimating the value of protecting deep-sea biodiversity. Ecological Economics 97, 10-19. https://doi.org/10.1016/j.ecolecon.2013.10.019

Liquete, C., Piroddi, C., Drakou, E.G., Gurney, L., Katsanevakis, S., Charef, A., Egoh, B. (2013). Current Status and Future Prospects for the Assessment of Marine and Coastal Ecosystem Services: A Systematic Review. PLoS One 8.

Mardle, S., Pascoe, S., Herrero, I. (2004). Management Objective Importance in Fisheries: An Evaluation Using the Analytic Hierarchy Process (AHP). Environmental Management 33, 1-11.

Micheli, F., Halpern, B.S., Walbridge, S., Ciriaco, S., Ferretti, F., Fraschetti, S., Lewison, R., Nykjaer, L., Rosenberg, A.A. (2013). Cumulative Human Impacts on Mediterranean and Black Sea Marine Ecosystems: Assessing Current Pressures and Opportunities. PLoS One 8.

Millennium Ecosystem Assessment (2005). Ecosystems and human well-being. Island press United States of America.

Remoundou, K., Koundouri, P., Kontogianni, A., Nunes, P.A.L.D., Skourtos, M. (2009). Valuation of natural marine ecosystems: an economic perspective. Environmental Science \& Policy 12, 10401051 . 
Rodríguez, J., Ruíz, J. (2010). Conservación y protección de ecosistemas marinos: conceptos, herramientas y ejemplos de actuaciones 19.

Saaty, T. (1987). The analytic hierarchy process — what it is and how it is used. Mathematical Modelling 9, $161-176$.

Saaty, T.L. (2004). Fundamentals of the analytic network process - Dependence and feedback in decisionmaking with a single network. J. Syst. Sci. Syst. Eng. 13, 129-157.

Saaty, T.L. (1990). How to make a decision: the analytic hierarchy process. European journal of operational research 48, 9-26.

Saaty, T.L. (1988). What is the analytic hierarchy process?, in: Mathematical Models for Decision Support. Springer, pp. 109-121.

Valenciana, G. (2019). Conselleria d'Agricultura i Pesca. Artisanal fisher in Xàbia 2015-2019 [Data set] Unpublished raw data.

Zahir, S. (1999). Clusters in a group: Decision making in the vector space formulation of the analytic hierarchy process. European Journal of Operational Research 112, 620-634. 